\title{
Evaluation of the pharmaceutical assistance structure in Maranhão State, Brazil
}

\author{
Flávio Donalwan Sá Maximino ${ }^{\circledR}{ }^{1 *}$, Maria Helena Seabra Soares de Brito², \\ Selma Rodrigues de Castilho ${ }^{3}$, Benedito Carlos Cordeiro ${ }^{3}$
}

\begin{abstract}
${ }^{1}$ Administration and Management of Pharmaceutical Assistance, Pythagoras College, São Luís, Brazil, ${ }^{2}$ Regional Center of Pharmaceutical Assistance, Pharmacy Course Maranhão Federal University, São Luís, Brazil, ${ }^{3}$ Department of Pharmacy and Pharmaceutical Administration. Pharmacy Course, Fluminense Federal University, Rio de Janeiro, Brazil
\end{abstract}

\begin{abstract}
Assessment instruments can measure the effectiveness of health policy organizations. This research is a descriptive diagnostic study the Pharmaceutical Assistance structure in Maranhão State, Brazil. The methodology consisted of obtaining secondary data from institutions related to the Pharmaceutical Assistance in the State. Structure indicators were calculated using methodology adapted from the World Health Organization (WHO), and pharmacists perception about the structure of the Pharmaceutical Assistance was analysed through questionnaires. There are 3,003 pharmacists and 3,410 healthcare establishments registered in the Regional Pharmacy Council CRF-MA, particularly in the capital area. Two main problems were identified by pharmacists: the "ineffective management of the public health system" and the "amount of available medicine is insufficient to meet the rising demands of the population" $(23.08 \% ; 18$ each). We concluded that the Pharmaceutical Assistance organization in Maranhão State is in a precarious situation that requires an investment of resources to improve the physical structures, expand the amount and improve the qualifications of human resources, and procure medicines in sufficient quantities to meet the population's needs.
\end{abstract}

Keywords: Pharmaceutical assistance. National medicament policy. Process assessment. Brazil Health System.

\section{INTRODUCTION}

Maranhão is one of the poorest states in the Brazilian federation, with the lowest rent per capita in the country (IMESC, 2010). In Brazil, health care became a right of all citizens conferred by the 1988 Constitution, through the National Health Act, which implemented the basis of the Unified Health System - also known as the SUS (Brasil, 1990; Brasil, 1988). The reality of many Brazilian municipalities is characterized by low-quality health services and a lack of resources that causes further difficulties with managing and structuring primary health care (Coriolano et al., 2010; Arretche, Marques, 2002).

The same low-quality of services is observed for the Pharmaceutical Assistance, defined by the National Board of Health as "a set of actions for the promotion, protection

\footnotetext{
*Correspondence: F. D. Sá Maximino. Faculdade Pitágoras - São Luís. Rua Lisboa Serra, n03, Cohab-Anil 3, São Luís - MA, CEP 65051-450. Phone: (98) 3258-5927. E-mail: flaviosamaximino@gmail.com
}

and recovery of health, both individual and collective, medicines as an essential element aiming to guarantee access to and its rational use" (Brasil, 2004).

Today, the Pharmaceutical Assistance cycle is discussed as the structuring of a sequence of activities that disregards the patient as the final recipient of these steps (OPAS/OMS, 2013). However, one cannot deny the importance of logistics activities, because, without them, access to medicines would simply not exist.

Management is defined as a technical process that requires analytical skills based on scientific knowledge (Leite, Guimarães, 2011). Pharmaceutical Assistance management of primary care is in considered the "ability to formulate, articulate and create conditions for the implementation and sustainability of Basic Pharmaceutical Assistance in a decentralized and shared manner at the municipal level", as proposed by Barreto and Guimarães (2010). Inefficiency in the management process can be observed in the structures available to the most diverse areas of the country, including the health and Pharmaceutical 
Assistance, and can be evaluated using indicators (Bernardi, Biebercach, Thomé, 2006; Marin et al., 2003).

Contandriopoulos et al. (1997) claim that evaluation is, fundamentally, having a value judgement about an intervention to assist in decision making. According to Donabedian (1984), a general evaluation of health quality is based on the concept of structure-process and result, using indicators applied to all system steps (Bernardi, Biebercach, Thomé, 2006; OPAS, 2005).

Structure is relevant to more stable aspects of the health system, including infrastructure, financial resources, materials and personnel necessary provide the desired attention and organization of these services (OPAS, 2005; Donabedian, 1984).

Data available in the literature about the Pharmaceutical Assistance developed in Maranhão State are scarce. Thus, the aim of this study was to the structure of the Pharmaceutical Assistance in public institutions of this state, to contribute to optimizing resources and promoting the rational use of medicines.

\section{MATERIAL AND METHODS}

This is a descriptive study, transverse and exploratory type, based on studies that evaluated the Pharmaceutical Assistance in other regions of the country (Bruns, 2013; Souza, Porto, Lyra, 2011; Freitas, Nobre, 2011; Barreto, Guimarães, 2010; Oliveira, Assis, Barboni, 2010; Vieira, Lorandi, Bousquat, 2008; Moura, 2008; Correia, 2007; Marin et al., 2003; Bernardi, Bieberbach, Thomé, 2006; Marcondes, 2002; Cosendey, 2000) The survey was conducted in sequential steps, using methods of triangulation, with quantitative and qualitative approaches, per the flowchart proposed in Figure 1.

The study was conducted in the main institutions related to the structure of the Pharmaceutical Assistance in the State of Maranhão: State Department of Health (SESMA), Health Municipal Secretariat of São Luís (SEMUS) and the Regional Pharmacy Council of Maranhão (CRFMA).

For secondary data, we excluded those that were incomplete, without proper sources, or that showed conflicting results. For Steps 1 and 2, the study was retrospective, covering the period from January 2003 to August 2014.

In Step 3, on the application of the questionnaires, the survey was conducted prospectively in the period from October to November 2014. All pharmacists working at public institutions of primary healthcare in Maranhão municipalities were invited, according to the CRF-MA information.

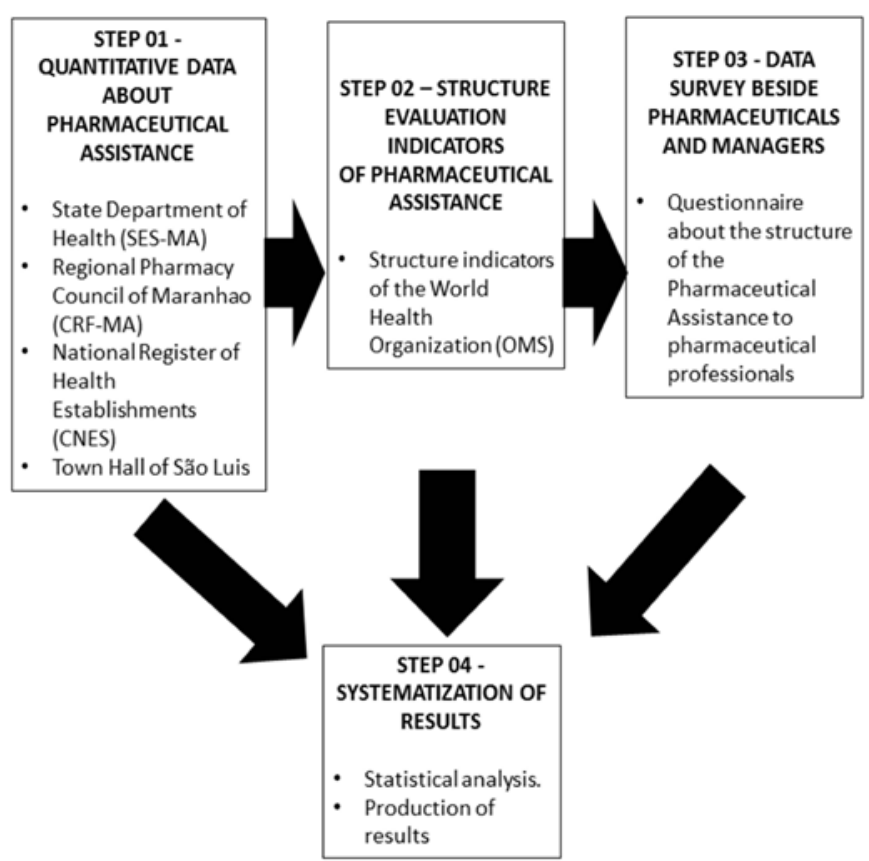

FIGURE 1 - Flowchart of methodological steps for development of pharmaceutical assistance evaluation activities in Maranhão State. Source: prepared by the author.

\section{Step 1 - Situational Analysis of the Health System and Pharmaceutical Assistance n Maranhão State}

An analysis to describe the structural aspects of the Pharmaceutical Assistance organization was conducted on open data and open access documents available in official public institutions. This allowed for the identification of official organization charts of these agencies, elucidating the management aspects of the Pharmaceutical Assistance developed in the state other than the number of establishments and registered pharmacists with their geographical distribution.

Data were also collected on the Pharmaceutical Assistance in Maranhão State available through the National Register of Health Establishments (CNES), which consists of a database to operationalize the Health Information System.

\section{Step 2 - Evaluation Indicators of the Pharmaceutical Assistance Structure in Maranhão State}

In the next stage, the methodological procedures used by the World Health Organization (WHO) were adapted to assess the Pharmaceutical Assistance in Maranhão State. We used the studies of Cosendey (2000), and Bernardi, Bieberbach and Thomé (2006) to adjust the indicators covering the first level evaluation proposed 
by Donabedian (1984): the structure. Rapid Assessment Method (RAM), used by Bruns (2013), was also adapted as a management tool for monitoring services routines due to socioeconomic and regional similarities observed between the states of Paraíba and Maranhão.

\section{Step 3 - Structural Data Collection from Pharmacists and Managers}

A questionnaire with 22 closed questions was directed to the pharmacists who worked in the municipal public institutions of the state. This instrument was adapted from the work done by Moura (2008) in the State of Amazonas and the "Questionnaire for Pharmaceutical Assistance Evaluation in the municipalities," developed by the Secretariat of Health and Civil Defense of Rio de Janeiro (2009). The questionnaire, available on a "Google Drive ${ }^{\circledR}$ " platform, was sent together with an "Informed Consent and Terms". November 16, 2014, was the deadline for completion and submission of responses.

\section{Step 4 - Systematization of Results and Ethical Aspects}

The quantitative and qualitative data collected in steps 1, 2 and 3 were statistically analysed using Microsoft Excel ${ }^{\circledR} 7.0$ software, considering simple descriptive aspects at a significance level of $95 \%$.

The request to perform this study was submitted for approval to the Research Ethics Committee (CEP) of the Fluminense Federal University (UFF) through the "Brazil Platform" and was approved with the number 559448/2014.

At the local level, in relation to the ethical aspects of Steps 1 and 2, the project proposal was sent together with a cover letter to the ethics committees of SES-MA, CRFMA and SEMUS from São Luís, requesting authorization to collect data.

The names of professionals who worked with the Pharmaceutical Assistance in the State of Maranhão during the analysis period were not disclosed. Likewise, no data concerning patients' names or their clinical conditions have been disclosed.

\section{RESULTS AND DISCUSSION}

\section{Step 1 - Quantitative data on pharmaceutical assistance in Maranhão state}

State Department of Maranhão Health (SES-MA)

The headquarters of the Maranhão Secretary of
Health is located in its capital of São Luís, following the regionalization model approved by the Bipartite Inter Commission (CIB), and is composed of 19 Regions and 8 Macroregions of Health, based on geographical and epidemiological criteria, which references all programmes and actions (Maranhão, 2012).

The Pharmaceutical Assistance actions are part of Performance Programmatic units and are allocated to the Management Unit of Strategic Inputs (UGIE), linked directly to the Secretary of Health and subdivided into three departments: a) Department of Exceptional Drugs; b) Department of Standardization of Pharmaceutical Assistance and c) Department of Nutritional Recovery.

The Department of Exceptional Drugs provides management of the Specialized Component of Pharmaceutical Assistance, represented by the State Pharmacy of Exceptional Medicines (FEME). This department is responsible both for the analysis of drug requests and for outpatient dispensation, carrying out the distribution to health macro-regions.

Regarding the selection of drugs, there is no Pharmacy and Therapeutics Committee (CFT) legally established in Maranhão, nor is there a State List of Essential Medicines. In practice, it follows a standardization of drugs based on the pact Basic Component Reference List, published in Resolution $n^{0} 214$ of the Bipartite Inter Commission (CIB/MA, 2010) and on the National List of Essential Medicines (RENAME). Overall, 332 items are part of the list of medicines available for primary healthcare. Other states and municipalities such as Amazonas State (Moura, 2008) and the city hall of João Pessoa - PB have a formally established CFT and lists of essential (Bruns, 2013).

Currently, to finance and acquire medicines, the Maranhão State Government makes monthly payments to the fund for services destined for municipalities, according to the amounts agreed to in the CIB/MA. UGIE also coordinates storage and distribution for the Center of Pharmaceutical Supply of the Maranhão State (CEAFMA), which is responsible for the management of drugs belonging to the Strategic and Specialized Components.

\section{City Hall of São Luís}

The capital São Luís is the reference location for the attendance to public health in Maranhão State, having most of the urgent care and emergency hospitals in the state. The focus of the study was to describe the "Superintendence of Healthcare Network (SARS)", responsible for scheduling, coordinating, monitoring, supervising and evaluating the services to be performed in the municipal network (São Luís, 1998). Hierarchically, there are 90 health establishments linked to the city hall and directly linked to 
SARS. The health facilities are divided geographically into seven Sanitary Districts, being situated in the countryside that comprises the basis for the division of the Family Health Strategy (ESF) teams in São Luís (1998).

The Pharmaceutical Assistance activities are assigned to the Department of Pharmacy and Biochemistry Coordination, linked to SARS. Officially there are no subdivisions in this sector but, in practice, the Center of Pharmaceutical Supply is responsible for storage and distribution of drugs to health facilities, and the Pharmaceutical Assistance Center is responsible for the care and dispensing of drugs obtained through lawsuits.

There is a total of 237 professionals related to the city hall: 78 pharmacists working in hospitals and health posts, 150 in clinical analysis and 9 as sanitary inspectors. According to the information provided by the Department of Pharmacy and Biochemistry Coordination, there is a high concentration of pharmacists in hospitals to the detriment of basic health units, where the presence of pharmacists is still incipient, showing an absence of pharmacists in the first level of care.

There has been no standard developed for the selection of drugs based on epidemiological parameters of the municipality. A similar situation was described by Souza, Porto and Lyra (2011) in the municipality of Sergipe.

To acquir medicines, the Pharmacy and Biochemistry Coordination Agency forwards the annual programme to the Superintendence of Material and Heritage (SUMAPA) which forwards the request to the Permanent Bidding Committee (CPL) of the municipality and follows the Bidding Law (Law $n^{0} 8.666 / 93$ ) through the price registration mode. After acquisition, the drugs are stored in the Central Warehouse of the City Hall and later distributed to the health units according to a previously established schedule.

The difficult access to information and the structural fragility observed herein is consistent with the findings of OPAS (2005) and Rodrigues and colleagues (2017).

\section{Regional Pharmacy Council of Maranhão (CRF-MA)}

Out of the total establishments registered at the CRFMA, 771 (22.61\%) belong to the three administrative levels of the public sector (federal, state and municipal), mostly represented by basic pharmacies (363), concentrated in São Luís (70; 19.28\%). A total of 546 (16.01\%) establishments are located in São Luís, while 2,864 (83.99\%) are in other municipalities.

According to the CRF-MA, in May 2014, there were 3,003 pharmacists with an active license, mostly in São Luís (1,572: 52.35\%). According to the last population census (IBGE, 2010), in 2010, the city of São Luís had $1,014,837$ inhabitants.

However, there is a low number of professionals in other municipalities, which makes it reasonable to conclude that there are pharmacies without the actual presence of a pharmacist, a serious sanitary infraction subject to penalties under the current legislation $n$. 13.021/14 (Brasil, 2014). This calculation is in accordance with the findings of Rodrigues and colleagues (2017) who observed that $54 \%$ of the municipalities studied did not have enough pharmacists to maintain services.

It is important to emphasize that Mendes and colleagues (2014), analysing data from primary care facilities in Brazil, observed a low percentage of pharmacies that had pharmacist support but noted there was a higher chance of drug dispensability when this support was present.

\section{National Register of Health Establishments(CNES)}

Analysing data from the National Register of Health Establishments (CNES), provided by the Ministry of Health, on the number of professionals situated in Maranhão, registered pharmacists numbered 1,515 in 2009 , and of these, 1,364 (90.04\%) met the SUS. These data differ almost $100 \%$ from those obtained at the CRFMA, suggesting probable underreporting in the CNES database in Maranhão.

\section{Step 2 - Structure assessment indicators of pharmaceutical assistance in Maranhão state}

The main results concerning the structure of the Pharmaceutical Assistance in Maranhão State were summarized in Table I.

Our assessment at this stage was hampered an absence of most of the elements corresponding to the indicators, especially by the SES-MA. This is in accordance with the low assessment of pharmaceutical assistance observed by Rodrigues and colleagues (2017) when analysing the structure axis implementation at SUS. Cosendey (2000) and Bruns (2013) also report in their studies that their analysis of the indicators could not be performed in its entirety, reinforcing our conclusion that the Pharmaceutical assistance is not effectively implemented in the country, especially in instances of SUS. The same difficulty was pointed out by the study of OPAS (2005).

The SES-MA structure does not have any official procedure available for selection, programming and acquisition of medicines, or rules and routines to assist municipalities with these steps. The public management 
TABLE I - Evaluation indicators of pharmaceutical assistance in Maranhão State

\begin{tabular}{|c|c|c|c|}
\hline \multicolumn{4}{|c|}{$\begin{array}{c}\text { SOCIO-DEMOGRAPHIC INFORMATION } \\
\text { HEALTH SITUATION AND THE HEALTH SYSTEM }\end{array}$} \\
\hline DIMENSION & INDICATOR & $\begin{array}{c}\text { DEFINITION } \\
\end{array}$ & RESULT \\
\hline \multirow[b]{2}{*}{ Population data } & Total population of the state & Number of inhabitants in the state & $6,574,789$ inhabitants \\
\hline & Life expectancy at birth & $\begin{array}{l}\text { Average number of years that a group } \\
\text { of individuals born in the same year } \\
\text { can expect to live }\end{array}$ & 69.98 \\
\hline \multirow{5}{*}{$\begin{array}{l}\text { Health System } \\
\text { Organization }\end{array}$} & $\begin{array}{l}\text { Organization Chart of the } \\
\text { Health Department }\end{array}$ & $\begin{array}{c}\text { Formal description of the } \\
\text { organizational structure and planning } \\
\text { of the State Health Secretariat }\end{array}$ & $\begin{array}{c}\text { Provisional Measure } \\
\text { № 082/2010; № Decree } \\
27,257 / 2011\end{array}$ \\
\hline & $\begin{array}{c}\text { Institutionalization of } \\
\text { Pharmaceutical Assistance }\end{array}$ & $\begin{array}{l}\text { Pharmaceutical assistance existence } \\
\text { on the Organization Chart of SES }\end{array}$ & $\begin{array}{l}\text { Management Unit of } \\
\text { Strategic Inputs (UGIE) }\end{array}$ \\
\hline & $\begin{array}{l}\text { Organization Planning of } \\
\text { Pharmaceutical Assistance }\end{array}$ & $\begin{array}{l}\text { Inclusion of Pharmaceutical } \\
\text { Assistance in the State Health Plan, } \\
\text { defining objectives and goals }\end{array}$ & $\begin{array}{c}\text { There is a description } \\
\text { of the State Health Plan } \\
\text { (2012-2015), but no defined } \\
\text { objectives or goals }\end{array}$ \\
\hline & $\begin{array}{c}\text { Actions Evaluation of } \\
\text { Pharmaceutical Assistance }\end{array}$ & $\begin{array}{l}\text { Existence of procedures for } \\
\text { monitoring through indicators }\end{array}$ & NO \\
\hline & $\begin{array}{c}\text { Events of Training / } \\
\text { Recycling of Professionals } \\
\text { in AF }\end{array}$ & $\begin{array}{l}\text { Number of Events and Capacitated } \\
\text { Professionals in the last five years }\end{array}$ & NO \\
\hline
\end{tabular}

\begin{tabular}{|c|c|c|c|}
\hline \multicolumn{4}{|c|}{ INFORMATION ABOUT THE STEPS OF THE CYCLE OF PHARMACEUTICAL ASSISTANCE } \\
\hline DIMENSION & INDICATOR & DEFINITION & RESULT \\
\hline \multirow[t]{2}{*}{ Medicine selection } & $\begin{array}{l}\text { Existence of the Pharmacy } \\
\text { and Therapeutics Committee } \\
\text { (CFT) }\end{array}$ & $\begin{array}{l}\text { Composed of members of the CFT } \\
\text { and the number of meetings }\end{array}$ & NO \\
\hline & State Relation of Medicines & $\begin{array}{c}\text { Adequacy of the state list in relation } \\
\text { to RENAME }\end{array}$ & NO \\
\hline
\end{tabular}

Financial Resources Used by the Municipalities for Drug Acquisition

Funding sources and quantification of budget resources
$\mathrm{R} \$ 6,590,254.07$

Municipal, Federal and State Counterpart from 2003 to 2013

NO

Programming realization of

the drug needs in accordance withrecommended methods, documented in calculation memory

Existence of a catalogue containing the technical specifications of medicines for edicts for municipal

NO acquisition

Medicines Acquired

$\begin{array}{cc}\text { Pharmaceutical Supply } & \begin{array}{c}\text { Quantity of Places for storing and } \\ \text { Centers (CAF) }\end{array} \\ \text { distribution of drugs }\end{array}$

1 State Central rules for proper storage of medicines and Transport

Warranty of Correct storage
in the Warehouse

Suitable transport
Warranty of Medicines

Existence of Standard Operating

Procedures (SOP) that describe the

Pharmaceutical Supply

Existence of SOPs describing the rules for the transport of drugs
NO

NO

Source: Adapted from Brazil (2006); Marin et al. (2003); Bernardi, Bieberbach, Thomé (2006); Cosendey (2000); Moura (2008); Souza, Porto, Lyra (2011); SES-MA - State Department of Health of Maranhão (2012); CRF-MA - Regional Pharmacy Council of Maranhão (2014); IBGE (2010). 
process of the State Pharmaceutical Assistance in Maranhão under employs programming activities and ineffectively procures drugs.

The lack of documents or official records regarding the storage, distribution and transport of medical supplies compromised our analysis, especially with regard to operational procedures that regulate the storage and transportation of drugs in the state.

\section{Step 3 - Structural data survey to the pharmacists and managers}

A total of 87 (23\%) questionnaires were answered by pharmacists registered in Maranhão. Nine were excluded due to incomplete responses or because they were incorrectly recorded. Therefore, a total of 78 responses were analysed.

Most pharmacists exercised their profession in the countryside of the State municipalities $(45 ; 58 \%)$, rather than in the capital São Luís (33; 42\%). There was a balance between two main sectors: 25 (32\%) pharmacists reported working in a hospital pharmacy, while 24 (30.77\%) worked in a basic pharmacy, followed by 11 who worked in the Center of Pharmaceutical Supply (CAF)/Warehouse $(14.10 \%)$.

Most professionals $(57 ; 73 \%)$ said that there is an agency or department responsible for Pharmaceutical
Assistance in the municipality, while $16(21 \%)$ responded that such a structure is not implemented and $5(6 \%)$ could not answer.

Regarding the frequency distribution of professionals, most of the analysed sectors reported the presence of two $(14 ; 17.95 \%)$ to three people $(15 ; 19.23 \%)$ working directly in Pharmaceutical Assistance (Table II). These data concur with those described by Moura (2008) in Amazonas State.

Most of the responses indicated that the selection of drugs is mainly carried out by the pharmacist responsible for their own health unit $(36 ; 51.43 \%)$, followed by the Pharmaceutical Assistance Coordination of the city (17; $24.29 \%$ ). Only 6 (8.57\%) responses refer to the Pharmacy and Therapeutics Commission (CFT), the same amount as those in which there is no criterion for the selection of drugs in the workplace.

Regarding the programming of medicines, the responses indicate that historical consumption (48; $61.54 \%$ ), based on the average of the previous months, is the main criteria used in Maranhão municipalities. It is noteworthy that only $9(11 \%)$ demonstrated the use of an epidemiological profile of the region. Moura (2008) also described the usage history as the primary criterion used for planning for medicines in Amazonian municipalities (22; 51.2\%).

Most of the complete responses indicated that the

TABLE II - Distribution Frequency of professionals directly involved with the pharmaceutical assistance in relation to workplace in Maranhão's municipalities $(\mathrm{N}=78)$

\begin{tabular}{ccc}
\hline $\begin{array}{c}\text { Number of People Directly Involved } \\
\text { with the Pharmaceutical Assistance }\end{array}$ & $\begin{array}{c}\text { Quantitative Responses } \\
\text { (N- absolute frequency) }\end{array}$ & $\begin{array}{c}\text { Percentage } \\
\text { (\% - Relative frequency) }\end{array}$ \\
\hline 1 & 4 & 5.13 \\
2 & 14 & 17.95 \\
3 & 15 & 19.23 \\
4 & 6 & 7.69 \\
5 & 7 & 8.97 \\
6 & 5 & 6.41 \\
7 to 8 & 4 & 5.13 \\
9 to 10 & 5 & 6.41 \\
11 to 15 & 2 & 2.56 \\
17 to 20 & 4 & 5.13 \\
21 to 30 & 5 & 6.41 \\
31 to 40 & 4 & 5.13 \\
41 to 70 & 3 & 3.85 \\
\hline TOTAL* & 78 & 100.00 \\
\hline
\end{tabular}

*NOTE: Median $=4.50 ;$ Mean = 10.26; Standard Deviation = 13.69. Source: prepared by the author. 
bidding process, the provisions of Law $n^{0} 8,666 / 93$, in its various forms was the main method used for the purchase of drugs in the municipalities $(44 ; 56.41 \%)$.

Much of the structure and procedures for carrying out the storage and distribution of drugsis the responsibility of municipal governments. Table III displays the main problems regarding the storage of medicines in Maranhão municipalities, according to pharmacists.

Policies and procedures for proper storage are essential for the development of pharmaceutical assistance, thus avoiding injury resulting from the loss of drugs and expected efficacy in the treatment (Marin et al., 2003). Thus, a specific location for the storage of medicines in health facilities is needed, containing equipment and adequate physical structures, according to current legislation; a situation that is not observed in Maranhão municipalities. This condition was also recognized by Mendes and colleagues (2014).

Inventory control organizes the storage of medicines and medical supplies. According to the data observed in the questionnaires, $88.46 \%$ (69) of professional pharmacists say that there is minimal inventory control in their workplace, while $11.54 \%$ (9) of the respondents have not observed such a system at all. Thirty-eight $(55.07 \%)$ of the respondents stated that inventory control, as developed in their health unit, is performed manually by shelf chips or improvised control books, reflecting a low level of structure in the Pharmaceutical Assistance of the State.

The main problem with the distribution of medicines to pharmacies in Maranhão is noncompliance to the schedule by the supply logistics providers $(22 ; 28.21 \%)$, followed by the absence of a supply schedule in the health service $(20 ; 25.64 \%)$, and resupply: the large gap of time between the request for drugs and receiving them in the health unit $(18 ; 23.08 \%)$. This gap probably occurs due to the division of responsibility for the procurement of drugs and an insufficient transportation framework, generating a high period of resupply.

The last activity of the Pharmaceutical Assistance Cycle refers to dispensing drugs. The survey responses show that the professional who performs most of this activity in Maranhão municipalities is a pharmacist $(27 ; 34.62 \%)$, followed by a pharmacy technician $(25$; $32.05 \%)$, then an administrative/general assistant (23; $29.49 \%$ ). In 3 responses (3.85\%), the doctor or nurse was the professional still responsible for most of the delivery of drugs to the patient, probably in places without the presence of a pharmacist.

This information is very concerning, considering that this is the stage that the pharmacist has contact with patients, the ultimate goal of all in this practice (Carvalho, 2014). In this scenario, not only is the user of the pharmaceutical services not receiving the attention he/ she deserves but also the service structure itself does not seem to present opportunities for pharmacists to dedicate themselves more to this service.

The last query on the questionnaire addressed the managerial aspects of Pharmaceutical assistance developed in Maranhão, providing an overview of the major obstacles experienced by pharmacists in the workplace, as provided in Table IV.

Table IV shows that inefficient management of the public health system and the number of drugs insufficient to serve the population's needs were the main problems pointed out by pharmacists of Maranhão, with 23.08\% (18) each.

TABLE III - Main problems of drug storage, according to pharmacists of Maranhão State $(n=78)$

\begin{tabular}{lcc}
\hline $\begin{array}{l}\text { What is the main problem or obstacle in drug STORAGE } \\
\text { in your workplace? }\end{array}$ & $\begin{array}{c}\text { Quantitative Responses } \\
\text { (N-absolute frequency) }\end{array}$ & $\begin{array}{c}\text { Percentage } \\
\text { (\% - Relative frequency) }\end{array}$ \\
\hline Insufficient available space for proper storage & 24 & 30.77 \\
Absence of structure and equipment for proper storage & 19 & 24.36 \\
Discrepancies between the amounts of drugs available in the & 18 & 23.08 \\
physical stock vs. inventory control & & 5.13 \\
There are no problems regarding storage & 4 & 3.85 \\
There are drugs in excessive amounts & 3 & 3.85 \\
There are drugs that have expired & 3 & 3.85 \\
There is no specific location for drugs storage and delivery & 3 & 5.13 \\
Others & 4 & 100.00 \\
\hline TOTAL & 78 & \\
\hline
\end{tabular}

Source: Prepared by the author. 
TABLE IV - Main obstacle to the organization of pharmaceutical assistance, according to pharmacists of Maranhão State $(\mathrm{n}=78)$

\begin{tabular}{lcc}
\hline $\begin{array}{l}\text { Main Obstacle to the Organization of Pharmaceutical } \\
\text { Assistance }\end{array}$ & $\begin{array}{c}\text { Quantitative Answers } \\
\text { (N - absolute frequency) }\end{array}$ & $\begin{array}{c}\text { Percentage } \\
\text { (\% - Relative frequency) }\end{array}$ \\
\hline Ineffective management of the public health system & 18 & 23.08 \\
Drug quantity insufficient to serve the population & 18 & 23.08 \\
Human resources (scarcity, training, professional enhancement & 16 & 20.51 \\
etc.) & 15 & 19.23 \\
Financial resources (insufficiency, absence, delay etc.) & 7 & 8.97 \\
Lack of physical infrastructure and insufficient and/or & & 5.13 \\
inadequate equipment & 4 & 100.00 \\
Other Causes. & 78 & \\
\hline TOTAL & &
\end{tabular}

Source: Prepared by the author.

Next, issues related to human resources (16; $20.51 \%)$ and the availability of financial resources (15; $19.23 \%$ ) were also cited as obstacles to the development of pharmaceutical assistance in the state. To a lesser extent, the infrastructure and equipment are inadequate or insufficient to carry out the required activities $(7 ; 8.97 \%)$. Other problems were also cited $(4 ; 5.13 \%)$, such as a lack of interest from pharmaceutical professionals and the speed of the process from bidding to the acquisition of medicines.

These responses confirmed the results discussed in Steps 1 and 2, showing that the Pharmaceutical Assistance organization in Maranhão State is in a precarious situation that requires an investment of resources to improve the physical structures, expand and improve the qualifications of human resources, and procure medicines in sufficient quantities to meet the population's needs.

\section{CONCLUSION}

Although the small amount of documentation of the pharmaceutical assistance process was the main limitation of this study, we were able to identify many problems with the pharmaceutical assistance structure in Maranhão. This study suggests that it is currently not able to provide a quality service to the population, hindering access to medicines and inadequately promoting the rational use of medicines.

Municipalities throughout the state have different problems regarding Pharmaceutical Assistance Cycle activities, mainly in inefficient inventory control, inadequate storage conditions and the failure to acquire drugs to dispense medicines without the quality that such a practice requires.
This study showed that the structure available for implementation and development of the Pharmaceutical Assistance organization in Maranhão is of a lower grade than that observed for the national average, the Northeast and other states such as the region of Paraiba and Amazonas State.

The main problems observed for the Pharmaceutical Assistance organization in Maranhão include ineffective management of the public health system; insufficient medicines to meet the needs of the population; scarcity of and low qualifications in human resources; low availability and use of financial resources; and inadequate physical infrastructure and available equipment.

The results of this research demonstrate the unpreparedness of public health management to lead and manage drug policies, contributing to the precarious situation in the structure of Pharmaceutical Assistance that developed in the state of Maranhão, especially in municipalities more remote from the capital.

This analysis permits the identification of interventions with the potential to contribute to improving pharmaceutical assistance structure. It is necessary to hire human resources to address the scarcity and low qualifications of pharmaceutical professionals and to develop and readjust activities related to the Pharmaceutical assistance cycle, especially in municipalities more remote from the metropolitan area. There is also the need to encourage Municipal Health Departments to submit projects to the "National Qualification of Pharmaceutical Assistance - QUALIFARSUS", which aims to improve the physical infrastructure of pharmaceutical establishments and the purchase of equipment for health facilities.

The use of consortiums to purchase medicines, a practice already adopted by other states, may provide a way 
to reduce the total costs for municipalities and represent a better process of acquisition. Some interventions that may contribute to improving the scenario observed also include implementing Pharmacy and Therapeutics Committees (CFT) to define the relationships and rosters of drugs at state and municipal levels; including the pharmacist in the health policies of municipalities through coordination with Pharmaceutical Assistance Municipal Plans; building Pharmaceutical Supply Centers (CAF) in the municipalities, thereby reducing problems related to storage and distribution of medicines to health facilities; and establishing mechanisms for planning, assessing and controlling the Pharmaceutical Assistance Cycle.

\section{REFERENCES}

Arretche M, Marques E. Municipalização da saúde no Brasil: diferenças regionais, poder do voto e estratégias de governo. Ciênc Saúde Colet. 2002;7(3):455-479.

Barreto JL, Guimaraes MCL. Avaliação da gestão descentralizada da assistência farmacêutica básica em municípios baianos. Brasil Cad Saúde Públ. 2010;26(6):1207-1220.

Bernardi CLB, Bieberbach EW, Thomé HI. Avaliação da Assistência Farmacêutica Básica nos Municípios de Abrangência da $17^{\text {a }}$ Coordenadoria Regional de Saúde do Rio Grande do Sul. Saúde Soc. 2006;15(1):73-83.

Brasil. Casa Civil. Lei no ${ }^{\circ}$ 13.021, de 08 de agosto de 2014. Dispõe sobre o exercício e a fiscalização das atividades farmacêuticas. Diário Oficial da União n. 152-A, 11 de agosto de 2014.

Brasil. Ministério da Saúde, Secretaria de Ciência, Tecnologia e Insumos Estratégicos, Departamento de Assistência Farmacêutica e Insumos Estratégicos. Assistência Farmacêutica na Atenção Básica: instruções técnicas para sua organização. $2^{\mathrm{a} e d . ~ B r a s i ́ l i a, ~ D F: ~ E d i t o r a ~ d o ~ M i n i s t e ́ r i o ~ d a ~ S a u ́ d e ; ~ 2006 . ~} 100$ pág. (Série A. Normas e Manuais Técnicos).

Brasil. Ministério da Saúde. Diário Oficial da União. Resolução do Conselho Nacional de Saúde (CNS) n ${ }^{0} 338$, de 06 de maio de 2004. Diário Oficial da União n. 96, Seção I, 20 de maio de 2004.

Brasil. Presidência da República. Casa Civil. Constituição da República Federativa do Brasil: texto constitucional promulgado em 5 de outubro de 1988. Diário Oficial da União n. 191-A, Seção I, 05 de outubro de 1988.
Brasil. Presidência da República. Casa Civil. Lei 8.080, de 19 de setembro de 1990. Dispõe sobre as condições para a promoção, proteção e recuperação da saúde, a organização e o funcionamento dos serviços correspondentes e dá outras providências. Diário Oficial da União, Brasília, n. 19, Seção 1, 19 de setembro de 1990.

Bruns SF. Política de Assistência Farmacêutica no Município de João Pessoa-PB: Contexto, Desafios e Perspectivas. [tese doutorado em Saúde Pública]. Rio de Janeiro: Escola Nacional de Saúde Pública Sergio Arouca; 2013.

Carvalho JM. A gestão orientada a processos aplicada a uma farmácia de um serviço de saúde da atenção primária à saúde. [Dissertação]. Niterói, RJ: Faculdade de Farmácia, Universidade Federal Fluminense; 2014.

Contandriopoulos AP, Champagne F, Denis JL, Pineaul TR. A avaliação na área da saúde: conceitos e métodos. In: Hartz ZMA (org.). Avaliação em Saúde: dos Modelos Conceituais à Prática na Análise da Implantação de Programas. Rio de Janeiro: FIOCRUZ; 1997. Cap. 02, p. 01-20.

Coriolano MW, Albuquerque GA, Araujo NS, Oliveira MA, Lima MM. Vivenciando o processo de municipalização do SUS no município de Juazeiro do Norte (CE). Ciênc Saúde Colet. 2010;15(5):2447-2454.

Correia ARF. Avaliação da Qualidade da Assistência Farmacêutica na Rede Pública Municipal de Atenção Primária de Saúde de Fortaleza - Ceará. [dissertação]. Fortaleza: Universidade Federal do Ceará; 2007.

CRF-MA. Regional Pharmacy Council of Maranhão. Relatório do Perfil Quantitativo de Profissionais e Estabelecimentos Farmacêuticos no Estado do Maranhão - 2014. Registro interno do Sistema CRF-MA.

Cosendey MAE. Análise da implantação do Programa Farmácia Básica: um estudo multicêntrico em cinco estados do Brasil. [Doutorado em Saúde Pública]. Rio de Janeiro: Escola Nacional de Saúde Pública, Fundação Osvaldo Cruz; 2000.

Donabedian A. La calidad de laatención médica: definicón e métodos de evaluación. 2. ed. México: La Prensa Médica Mexicana; 1984.194 p.

Freitas JMSM, Nobre ACL. Avaliação da assistência farmacêutica do município de Mombaça-Ce. Rev Bras Farm Hosp Serv Saúde. 2011;2(1):15-2011. 
Instituto Brasileiro de Geografia e Estatística. IBGE. Censo Demográfico 2010. [Acessado em 02 jun. 2014]. Disponível em: http://www.ibge.gov.br/home/estatistica/populacao/censo2010/ sinopse/default_sinopse. shtm.

Instituto Maranhense de Estudos Socioeconômicos e Cartográficos. Imesc. Indicadores de conjuntura econômica. São Luís, MA; 2010. 49 p.

Leite SN, Guimarães MCL. Planejamento em saúde. Módulo Transversal 1: gestão da assistência farmacêutica. Florianópolis: Editora UFSC; 2011.33 p.

Maranhão (Estado). Governo do Estado. Secretaria de Estado da Saúde. Assessoria de Planejamento. Plano Estadual de Saúde 2012-2015. São Luís, MA; 2012. 287p.

Maranhão (Estado). Comissão Intergestores Bipartite do Maranhão (CIB/MA). Diário Oficial do Estado do Maranhão. Resolução $\mathrm{n}^{0} 214$, de 20 de dezembro de 2010. Dispõe sobre a aprovação do novo elenco de Referência do Componente Básico.

Marcondes NSP. A Assistência Farmacêutica e o Uso de Medicamentos na Zona Urbana do Município de Ponta Grossa Paraná: Estudo de Caso. 2002. Rio de Janeiro. 157 p. Dissertação (Mestrado em Saúde Pública), Escola Nacional de Saúde Pública (ENSP), Fundação Oswaldo Cruz (FIOCRUZ). Rio de Janeiro.

Marin N, Luiza VL, Osorio-de-Castro CGS, Machado-dosSantos S. Assistência farmacêutica para gerentes municipais de saúde. Rio de Janeiro: OPAS/OMS; 2003. 373 p.

Mendes LV, Campos MR, Chaves GC, da Silva RM, Freitas PS, Costa KS, Luiza VL. Disponibilidade de medicamentos nas unidades básicas de saúde e fatores relacionados: uma abordagem transversal. Saúde Debate [online]. 2014;38(n. esp):109-123.

Moura ACS. Análise da organização e estruturação da assistência farmacêutica nos municípios do estado do Amazonas. [Monografia - Especialização em Gestão em Assistência Farmacêutica]. Fortaleza: Escola de Saúde Pública do Ceará; 2008.

Oliveira LCF, Assis MMA, Barboni AR. Avaliação da Assistência Farmacêutica em um Município da Bahia, Brasil. Rev. Baiana Saúde Públ. 2010;34(4):853-864.
Organização Pan-Americana da Saúde. Ministério da Saúde. OPAS/MS. Avaliação da Assistência Farmacêutica no Brasil. 1. Ed. Brasília - DF: Editora do Ministério da Saúde; 2005. 260 pág. - (Série técnica medicamentos e outros insumos essenciais para a saúde).

Organização Pan-Americana da Saúde. Organização Mundial da Saúde. OPAS/OMS. Servicios farmacéuticos basados en la atención primaria de salud. (La Renovación de la Atención Primaria de Salud en las Américas, n.6). Documento de posición de la OPAS/OMS. 1. Ed. Washington - DC: OPAS; 2013. 106 pág.

Rio de Janeiro (Estado). Superintendência de Assistência Farmacêutica e Insumos Estratégicos. Questionário para Avaliação da Assistência Farmacêutica nos Municípios, 2009. [Acessado em 02 Ago 2014]. Disponível em: www.saude.rj.gov. br/arquivos-para-baixar/doc download/15-questionario-paraavaliacao-da-assistencia-farmaceutica-nos-municipios.html.

Rodrigues PS, Cruz MS, Tavares NUL. Avaliação da implantação do Eixo Estrutura do Programa Nacional de Qualificação da Assistência Farmacêutica no SUS. Saúde Debate. 2017;41(n. esp):192-208

São Luís (Cidade). Prefeitura Municipal. Lei n ${ }^{0} 3.677$, de 08 de abril de 1998. Dispõe sobre a reestruturação organizacional da secretaria municipal de saúde e dá outras providências.

Souza LS, Porto JG, Lyra JDP. Avaliação da Estrutura e dos Processos de Organização e Gestão da Assistência Farmacêutica em Município do Estado de Sergipe. Rev Ciênc Farm Básica Apl. 2011;32(3):403-410.

Vieira MRS, Lorandi PA, Bousquat A. Avaliação da assistência farmacêutica à gestante na rede básica de saúde do Município de Praia Grande, São Paulo, Brasil. Cad Saúde Pública. 2008;24(6):1419-1428.

Received for publication on $24^{\text {th }}$ September 2016 Accepted for publication on $16^{\text {th }}$ April 2018 